\title{
Inhibition of testicular LDH-X from laboratory animals and man by gossypol and its isomers
}

\author{
I. D. Morris, C. Higgins and S. A. Matlin* \\ Department of Pharmacology, Materia Medica and Experimental Therapeutics, Medical School, \\ University of Manchester, Oxford Road, Manchester M139PT and *Department of Chemistry, \\ The City University, Northampton Square, London EC1VOHB, U.K.
}

\begin{abstract}
Summary. The inhibitory effect of $(+)-,(-)-,( \pm)$-gossypol and $( \pm)$-gossypol acetic acid upon testicular cytosolic LDH-X was measured in vitro. Gossypol acetic acid $(0-100 \mu \mathrm{mol} / \mathrm{l})$ inhibited LDH-X prepared from the testes of the mouse $>$ rabbit $>$ human $>$ rat $>$ hamster. There was no relationship between inhibition and in-vivo antifertility activity. LDH activity measured in vitro in serum of men and hamsters was unaffected by gossypol. Gossypol and its isomers were non-competitive inhibitors of human and hamster LDH-X with respect to the coenzyme NADH, competitive inhibitors of human LDH-X and noncompetitive-competitive inhibitors of hamster LDH-X with respect to the substrate $\alpha$-ketobutyrate. Co-incubation with human serum albumin or poly-L-lysine but not lysine protected human and hamster LDH-X from gossypol.
\end{abstract}

\section{Introduction}

Gossypol, a polyhydroxylated binaphthalene extracted from the cotton plant, is an effective oral male contraceptive. Infertility, associated with immotile spermatozoa, subsequent azoospermia and few side effects, has been reported from large clinical trials in China and smaller studies in Austria and Brazil (see Segal, 1985). In spite of this clinical application the antifertility mechanism remains unknown. Recent experiments suggest that the antifertility properties of gossypol are associated specifically with the (-)-isomer (Waller et al., 1983; Matlin et al. 1985). The apparent selectivity of gossypol towards mature and developing spermatozoa suggests that they possess a unique target. Whilst many of the cellular and biochemical properties of the testis may be found elsewhere in the body, lactate dehydrogenase (LDH: EC 1.1.1.27) is of interest. A specific isoenzyme $\mathrm{LDH}-\mathrm{X}$ is found only in germ cells, appearing first in pachytene spermatocytes (Sarkar, Dubey, Banerji \& Shah, 1978). LDH-X is essential for the metabolic activities in cells in the later stages of spermatogenesis (Jutte, Grootegoed, Rommerts \& van der Molen, 1981). That inhibition of this enzyme may account for the antifertility activity of gossypol was first suggested by Lee \& Malling (1981) and numerous reports have confirmed this in-vitro observation (Lee, Moon, Yuan \& Chen, 1982; Tso \& Lee, 1982; Giridharan, Bamji \& Sankaram, 1982; Eliasson \& Virji, 1983; Olgiati \& Toscano, 1983; Hoffer, 1985). However, many testicular and non-testicular enzymes can be inhibited by gossypol which raises the possibility that this interaction may not be related to the antifertility properties of gossypol (see Segal, 1985). This paper describes the interaction of gossypol with LDH-X prepared from the testes of a variety of species, susceptible and unsusceptible, to the antifertility effects of gossypol and attempts to try and elucidate the importance of the in-vitro inhibition. 


\section{Materials and Methods}

Racemic gossypol acetic acid (a gift from N.I.H., U.S.A.) was routinely recrystallized (melting point $183^{\circ} \mathrm{C}$ ) from ethyl acetate and stored dry in the dark until immediately before use. Gossypol, as the $( \pm)-,(+)$ - and (-)-isomers, was prepared as described elsewhere (Matlin et al., 1985). The doses and concentrations always refer to the content of the binaphthyl. Gossypol was diluted in ethanol and added directly to the assay tubes, while controls received ethanol alone (final concentration $1 \cdot 7 \% \mathrm{v} / \mathrm{v}$ ).

Testes were stored whole in liquid nitrogen until used. Human testes were obtained from patients (aged 58-65 years) undergoing surgery for inguinal hernia; spermatogenesis was normal when examined histologically in frozen sections. Testes were obtained from rabbits, rats (SpragueDawley) and mice (Swiss albino), which were not susceptible to the antifertility effect of gossypol, and the golden hamster which is susceptible to gossypol (see below for further details). Cytosol fractions were prepared according to the method described by Giridharan et al. (1982) and stored in liquid nitrogen until required for assay. Serum from men and adult hamsters was also prepared as a source of the other LDH-isoenzymes.

LDH-X assay conditions were based upon selective substrate utilization as described by Schatz \& Segal (1969). Substrates (Sigma Chemical Co. Ltd, Poole, Dorset, U.K.), pyruvate, $\alpha$-ketobutyrate, $\alpha$-ketovalerate, $\alpha$-ketoglutarate and NADH, were prepared in sodium potassium phosphate buffer $(100 \mathrm{mmol} / 1, \mathrm{pH} \mathrm{7 \cdot 4)}$. Optimization of enzyme, and substrate concentrations as well as specificity towards LDH-X was as indicated by Wilkinson \& Withycombe (1965), Lee et al. (1982), Tso \& Lee (1982), Giridharan et al. (1982), Eliasson \& Virji (1983), Olgiati \& Toscano (1983) and Hoffer (1985) and demonstrated in preliminary experiments. Enzyme activity was observed at $37^{\circ} \mathrm{C}$ by the change in absorbance of NADH at $340 \mathrm{~nm}$ using a Shimadzu recording spectrophotometer. Cytosols were diluted to achieve a linear plot to estimate rate of change.

\section{Results}

The in-vivo antifertility effects of gossypol in man and the lack of antifertility action in the rabbit are reported elsewhere (see Segal, 1985). As fertility studies have not previously been reported from our laboratories a brief description follows (for further details see Higgins (1985) and Higgins \& Morris (1985)). Rats received oral gossypol ( $20 \mathrm{mg} / \mathrm{kg}$ daily); 4 out of 6 rats died between 10 and 24 days of treatment associated with profound loss of body weight. Histological examination of the testes showed no abnormalities. Haematocrit and haemoglobin concentrations decreased by $50 \%$. Mice received orally between 6 and $100 \mathrm{mg}$ gossypol $/ \mathrm{kg}$ daily. The mice treated with 6,12 and $25 \mathrm{mg} / \mathrm{kg}$ survived treatment, mated normally and fertility in mated female mice was measured every 7 days for 63 days. Litter sizes were not changed. Hamsters treated with $5 \mathrm{mg}$ gossypol $/ \mathrm{kg}$ (by mouth, daily) for 35 days but not for 20 days and with $20 \mathrm{mg} / \mathrm{kg}$ for 20 days were significantly subfertile; hamsters treated with $20 \mathrm{mg} / \mathrm{kg}$ for 35 days were completely infertile. Infertility was assessed by implantation sites in mated females. Sperm motility in vitro was reduced. Testicular weight was unchanged at $20 \mathrm{mg} / \mathrm{kg}$ but raised in the $5 \mathrm{mg} / \mathrm{kg}$ group; other organ weights were unchanged. Histology revealed a disorganized spermatogenic epithelium only after 35 days of treatment with $20 \mathrm{mg} / \mathrm{kg}$.

Concentration-dependent inhibition of LDH-X activity was demonstrated for all the enzyme activities examined (Fig. 1). The susceptibility of the testicular cytosolic enzyme to gossypol was mouse $>$ rabbit $>$ human $>$ rat $>$ hamster. The EC-50 values ranged from $15 \mu \mathrm{mol} / 1$ (mouse) to $70 \mu \mathrm{mol} / \mathrm{l}$ (hamster). LDH activity in the serum of man and hamster was measured using pyruvate $(1 \mathrm{mmol} / \mathrm{l})$ and NADH $(17 \mathrm{mmol} / \mathrm{l})$ as the substrates in the presence of 10,50 or $100 \mu \mathrm{mol}$ gossypol/l. No inhibition of enzyme activity was seen at these concentrations. 


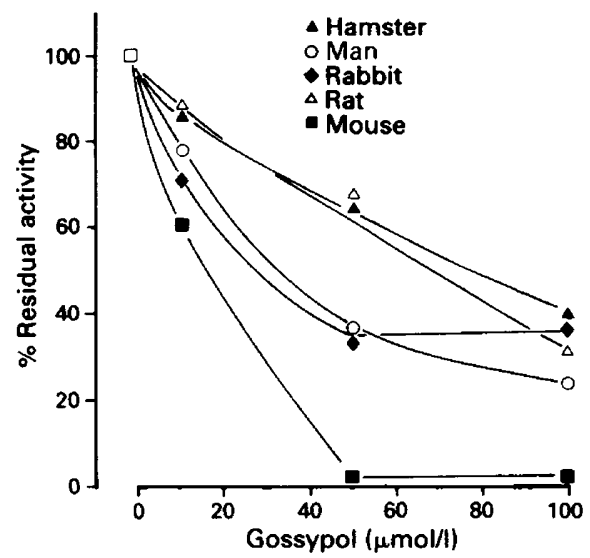

Fig. 1. Effect of gossypol upon testicular LDH-X in vitro. Gossypol was preincubated with testicular cytosol for $15 \mathrm{~min}$ before the addition of substrates. The substrate concentrations were $1 \mathrm{mmol} \alpha$-ketobutyrate $/ 1$ and $0.17 \mathrm{mmol} \mathrm{NADH} / 1$ for hamster, man and rabbit and $4.1 \mathrm{mmol} \alpha$-ketoglutarate $/ 1$ and $0.17 \mathrm{mmol} \mathrm{NADH} / 1$ for rat and mouse. The results are the mean of at least 3 separate determinations.

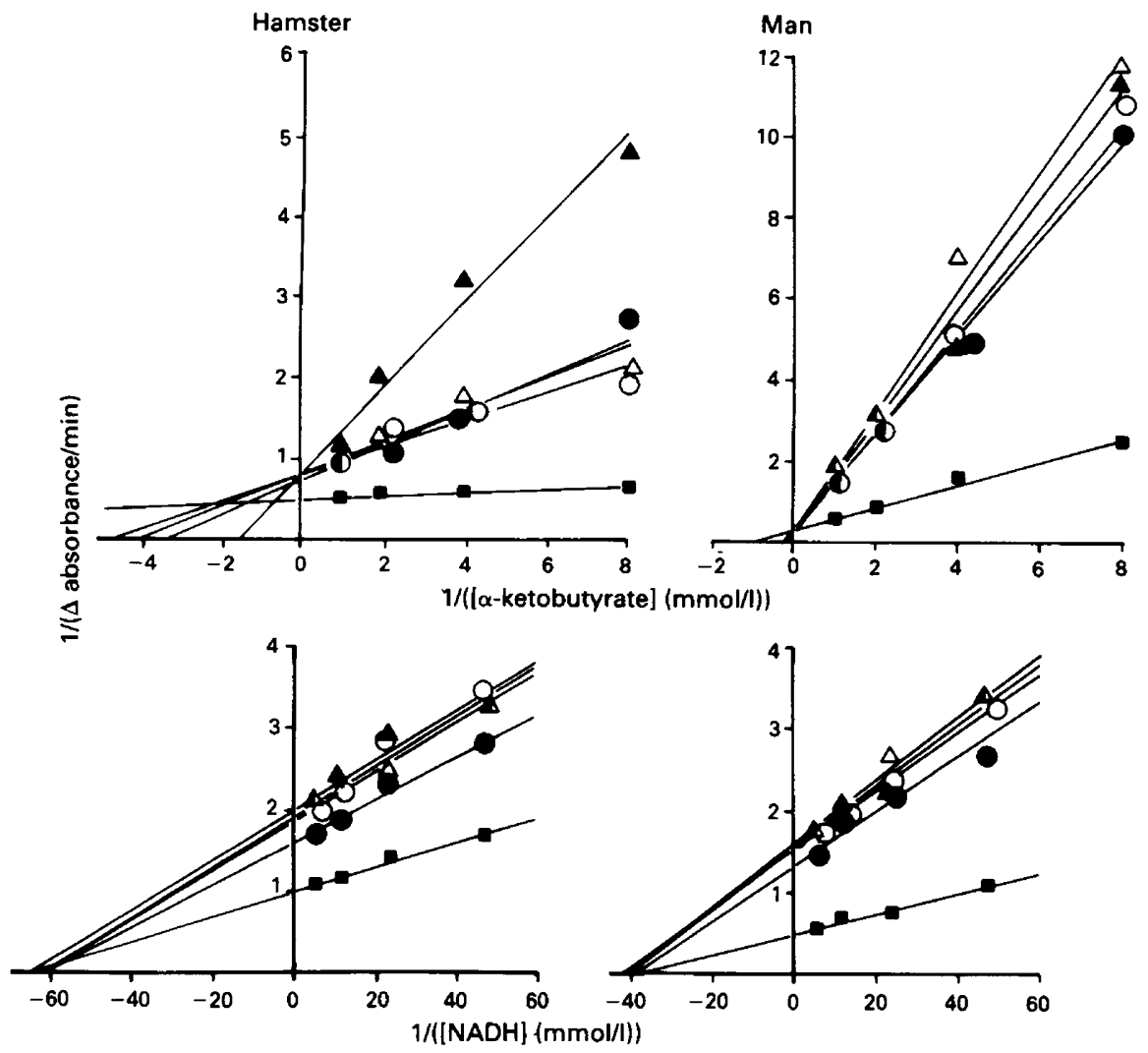

Fig. 2. Kinetics of the inhibition of testicular LDH-X activity by gossypol $(50 \mu \mathrm{mol} / \mathrm{l})$. Cytosols were preincubated for $15 \mathrm{~min}$ with gossypol before addition of the substrate. Incubates in which $\alpha$-ketobutyrate concentrations were varied contained $0.17 \mathrm{mmol} / 1 \mathrm{NADH}$. Incubates in which NADH concentrations were varied contained $1 \mathrm{mmol} / \mathrm{l} \alpha$-ketobutyrate. Each point is the mean of 3 observations. $\mathbf{\square}$, Control; $\boldsymbol{\Delta},(-)$-gossypol; $\triangle,(+)$-gossypol; $\bigcirc,( \pm)$-gossypol; $( \pm)$-gossypol acetic acid. 
The kinetics of LDH-X inhibition by gossypol preparations ( $50 \mu \mathrm{mol} / \mathrm{l})$ were examined (Fig. 2$)$. In human and hamster testicular cytosols the inhibition by gossypol was noncompetitive with respect to NADH. Gossypol decreased the $V_{\max }$ by $\sim 50 \%$. Little if any change was noted for $K_{\mathrm{m}}$. The inhibition of hamster LDH-X was more complex when using $\alpha$-ketobutyrate as the substrate and can be described as mixed inhibition, competitive-noncompetitive. The results indicate that (-)-gossypol is a more potent inhibitor of hamster LDH-X than is the racemate or the (+)-isomer when using $\alpha$-ketobutyrate as the substrate. The inhibition of human LDH-X by gossypol using $\alpha$-ketobutyrate as the substrate was competitive.

When the inhibitory effects ( $\%$ of control, mean \pm s.e.m., $n=3)$ of $( \pm)$-gossypol acetic acid $(50 \mu \mathrm{mol} / \mathrm{l})$ upon human $(60 \pm 8)$ and hamster $(31 \pm 4)$ testicular LDH-X were tested by addition of human serum albumin (HSA), poly-L-lysine $(50 \mu \mathrm{mol} / \mathrm{l})$ and L-lysine $(100 \mu \mathrm{mol} / \mathrm{l}) 15 \mathrm{~min}$ before inclusion of $1 \mathrm{mmol} \alpha$-ketobutyrate/l and $0.17 \mathrm{mmol} \mathrm{NADH} / 1$, the values for human and hamster respectively were: $100 \pm 1$ and $100 \pm 1$ with $0.4 \mathrm{mg} \mathrm{HSA} / \mathrm{ml}, 70 \pm 1$ and $43 \pm 2$ for gossypol $+0 \cdot 1 \mathrm{mg} \mathrm{HSA} / \mathrm{ml}, 96 \pm 1$ and $80 \pm 1$ for gossypol $+0.4 \mathrm{mg} \mathrm{HSA} / \mathrm{ml}, 98 \pm 2$ and $102 \pm 1$ for poly-L-lysine, $84 \pm 1$ and $91 \pm 1$ for gossypol + poly-L-lysine, $98 \pm 1$ and $99 \pm 1$ for lysine, and $63+1$ and $36 \pm 1$ for gossypol + lysine.

\section{Discussion}

Gossypol $(0-100 \mu \mathrm{mol} / 1)$ produced a concentration-dependent inhibition of testicular cytosol $\mathrm{LDH}-\mathrm{X}$ for all species examined. The EC-50 concentrations which ranged from 15 to $70 \mu \mathrm{mol} / 1$ are very similar to those reported by others (Lee et al., 1982; Tso \& Lee, 1982; Giridharan et al., 1982; Eliasson \& Virji, 1983; Olgiati \& Toscano, 1983; Hoffer, 1985), but there is a great deal of variation of the reported values which confuses the significance of such estimations. The present study was undertaken to avoid comparisons between laboratories and to see whether there was a relationship between antifertility effects in vivo and in-vitro inhibition of LDH-X. No relationship could be observed; for instance the mouse was most and the hamster one of the least susceptible to LDH-X inhibition by gossypol in complete contrast to our antifertility data. Some degree of selectivity for the testicular LDH-X appears to have been demonstrated in the present experiments as gossypol failed to inhibit LDH in the serum. These results would support the observation of the selective inactivation of testicular LDH-X reported by Lee et al. (1982), although this has been questioned by Hoffer (1985).

The kinetics of the inhibitory effect of gossypol upon LDH-X were examined in two susceptible species, man and hamster, but the type of inhibition was different and would not be consistent with a common in-vivo mechanism of action. Inhibition of hamster and human LDH-X was noncompetitive with respect to NADH. This suggests that gossypol may bind to LDH-X and the enzyme substrate complex is unaffected. However, the possibility remains that the inhibition was essentially irreversible which would also appear to reduce the $V_{\max }$. Gossypol inhibited LDH-X prepared from hamster testis by a mixed competitive-noncompetitive inhibition with respect to $\alpha$-ketobutyrate, which indicates that gossypol binds to the enzyme and enzyme substrate complex as well as competing for the active site. Inhibition of human testicular LDH-X was competitive with respect to $\alpha$-ketobutyrate, suggesting that gossypol competes with the substrate for the active site. Similar complex patterns of in-vitro inhibition have been reported for rat and cattle testicular LDH-X (Lee et al., 1982; Giridharan et al., 1982). In all but one experiment there is no suggestion of increased potency of any gossypol sample or isomer on the inhibition of LDH-X in vitro. However (-)-gossypol was slightly more potent upon hamster LDH-X when $\alpha$-ketobutyrate was the substrate and it is this isomer that is believed to possess more potent antifertility activity (Matlin et al., 1985). In general these results provide evidence to suggest that LDH-X inhibition in vivo is not a primary contribution to the antifertility effect produced by gossypol, especially since 
LDH-X inhibition in vitro is produced by the (+)-isomer which lacks antifertility properties (Waller et al., 1983; Matlin et al., 1985).

One of the numerous chemical reactions of gossypol is the formation of Schiff bases with lysine residues of protein (Conkerton \& Frampton, 1959). Inactivation of pig LDH-M4 and mouse LDH-X by pyridoxal-5-phosphate has been suggested to be due to modification of a single lysine residue (Gould \& Engel, 1980). Gossypol inhibits pepsinogen by binding to lysine residues so this effect may account for most of the in-vitro activity (Wong, Nakagawa \& Perlman, 1972). The present experiment would substantiate this. Human serum albumin completely protected the enzyme as did poly-L-lysine but not L-lysine. These observations would also indicate why apparent selectivity was seen in the present experiments. Human serum albumin binds with very high affinity to gossypol, $K_{\mathrm{D}}$ about $1 \times 10^{-9} \mathrm{~mol} / 1$ (Royer \& van der Jagt, 1983), which is several orders of magnitude higher than the affinity of gossypol for LDH-X that can be surmised from the EC-50 concentrations, $15-70 \times 10^{-6} \mathrm{~mol} / 1$. Serum contains $\sim 34 \mathrm{mg}$ albumin $/ \mathrm{ml}$ (Diem \& Lentner, 1970) and so is present in a large excess and would bind gossypol, possibly by the lysine residues, and so decrease the concentration to which enzymes were exposed. Protein binding may also be relevant to all experiments which use unpurified LDH or indeed any other target, the presence of proteins markedly influencing the potency of gossypol and so contributing to the variability of results in the literature. The role of protein binding by gossypol must be significant and should not be overlooked when designing in-vitro or in-vivo experiments; it probably contributes to the difficulty in interpreting results such as those presented in this study.

We thank the British Cotton Growers Association Ltd, the Wellcome Trust and the World Health Organisation Special Programme of Research in Human Reproduction for support and $\mathrm{Mr}$ I. McLennan (Manchester Royal Infirmary) for the human tissue.

\section{References}

Conkerton, E.J. \& Frampton, V.L. (1959) Reaction of gossypol with free E-amino groups of lysine in proteins. Archs Biochem. Biophys. 81, 130-134.

Diem, K. \& Lentner, C. (Eds) (1970) Documenta Geigy, Scientific Tables 1970, 7th edn. J. R. Geigy, Basle.

Eliasson, R. \& Virji, M. (1983) Effects of gossypol acetic acid on the activity of LDH-C4 from human and rabbit spermatozoa. Int. J. Androl. 6, 109-120.

Giridharan, N., Bamji, M.S. \& Sankaram, A.V.B. (1982) Inhibition of rat testis $\mathrm{LDH}-\mathrm{X}$ activity by gossypol. Contraception 26, 607-615.

Gould, K.G. \& Engel, P.C. (1980) Modification of mouse testicular lactate dehydrogenase by pyridoxal5-phosphate. Biochem. J. 191, 365-371.

Higgins, C. (1985) Gossypol toxicity and anti-fertility action-studies of possible mechanisms. Ph.D. thesis, University of Manchester.

Higgins, C. \& Morris, I.D. (1985) Fertility and LDH-X activity in male hamsters treated with the male contraceptive gossypol. IRCS (Med. Sci.) 13, $1064-1065$.

Hoffer, A.P. (1985) Ultrastructural, biochemical and endocrine studies on the effects of gossypol and its isomeric derivatives on the male reproductive tract. In Gossypol. A Potential Contraceptive for Men, pp. 143-186. Ed. S. J. Segal. Plenum Press, New York.

Jutte, N.H.P.M., Grootegoed, J.A., Rommerts, F.F.G.
\& van der Molen, H.J. (1981) Exogenous lactate is essential for metabolic activities in isolated rat spermatocytes and spermatids. J. Reprod. Fert. 62, 399-405.

Lee, C.Y.G. \& Malling, H.V. (1981) Selective inhibition of sperm specific lactate dehydrogenase-X by an antifertility agent, gossypol. Fedn Proc. Fedn Am. Socs. exp. Biol. 40, 718, Abstr. 2790.

Lee, C.Y.G., Moon, Y.S., Yuan, J.H. \& Chen, A.F. (1982) Enzyme inactivation and inhibition by gossypol. Molec. cell. Biochem. 47, 65-70.

Matlin, S.A., Zhou, R., Bialy, G., Blye, R.P., Naqvi, R.H. \& Lindberg, M.C. (1985) (-)-Gossypol, an active male antifertility agent. Contraception 31, 141-149.

Olgiati, K.L. \& Toscano, W.A. (1983) Kinetics of gossypol inhibition of bovine lactate dehydrogenase $\mathbf{X}$. Biochem. Biophys. Res. Comun. 115, 180-185.

Royer, R.E. \& van der Jagt, D.L. (1983) Gossypol binds to a high affinity site on human serum albumin. FEBS Letters 157, 28-30.

Sarkar, S., Dubey, A.K., Banerji, A.P. \& Shah, P.N. (1978) Patterns of lactate dehydrogenase isozymes during gonadogenesis in the rat. J. Reprod. Fert. 53, 285-288.

Schatz, L. \& Segal, H.L. (1969) Reduction of $\alpha$ ketoglutarate by homogenate lactic dehydrogenase-X of testicular tissue. J. biol. Chem. 244, 4393-4397. 
Segal, S.J. (Ed.) (1985) Gossypol. A Potential Contraceptive for Men. Plenum Press, New York.

Tso, W.W. \& Lee, C.S. (1982) Lactate dehydrogenase$\mathrm{X}$, an isozyme particularly sensitive to gossypol inhibition. Int. J. Androl. 5, 205-209.

Waller, D.P., Bunyapraphatsara, N., Martin, A., Vournazos, C.J., Ahmed, M.S., Soejarto, D.D., Cordell, G.A., Fong, H.H.S., Russell, L.D. \& Malone, J.P. (1983) Effect of ( \pm )-gossypol on fertility in male hamster. J. Androl. 4, 276-279.
Wilkinson, J.H. Withycombe, W.A. (1965 Organ specificity and lactate-dehydrogenase activity. Some properties of human spermatozoal lactate dehydrogenase. Biochem. J. 97, 663-668.

Wong, R.C., Nakagawa, Y. \& Perlman, G.E. (1972) Studies on the nature of the inhibition by gossypol of the transformation of pepsinogen to pepsin. J. biol. Chem. 247, 1625-1631.

Received 22 November 1985 